\title{
INTERCROPPING GARLIC (Allium sativum) WITH CHILLI (Capsicum annuum L.) IN THE HAOR AREA OF KISHOREGANJ
}

\author{
M.F. Khatun ${ }^{1}$, M.S. Islam ${ }^{2}$, M.A. Ali ${ }^{3}$, M.O. Ali ${ }^{4}$ and Q.M. Ahmed ${ }^{1}$ \\ 1SO, PGRC, Bangladesh Agricultural Research Institute, Gazipur; ${ }^{2} \mathrm{SSO}$, OFRD, Bangladesh Agricultural \\ Research Institute, Kishoreganj-2300; ${ }^{3} \mathrm{CSO}$, OFRD, Bangladesh Agricultural Research Institute, Gazipur; \\ ${ }^{4} \mathrm{CSO}, \mathrm{PRSS}$, Bangladesh Agricultural Research Institute, Gazipur \\ "Corresponding E-mail: mfkhatun79@gmail.com
}

Received: 27 July 2020, Accepted: 09 August, 2020)

Keywords: Intercropping, haor, chilli, garlic, equivalent yield, economic return

\begin{abstract}
Haor is one of the uncertain areas for crop production and productivity in Bangladesh. Traditionally, single cropping practice in a short cropping season is the key obstacle to increase crop productivity. A study was carried out at Multi Location Testing site (MLT), Nikly under the On-Farm Research Division (OFRD), Bangladesh Agricultural Research Institute (BARI), Kishoreganj at haor area during the two consecutive Rabi seasons of 2015-16 and 2016-17 to evaluate the performance of garlic with chilli intercropping system, its productivity and economic viability. Four treatments were consisted viz., sole chilli, one row garlic in between chilli rows, double rows garlic in between chilli rows and garlic with broadcasting chilli. The highest chilli equivalent yield $\left(28 \mathrm{t} \mathrm{ha}^{-1}\right)$ was obtained from one row garlic in between chilli rows and the minimum chilli equivalent yield was $\left(15 \mathrm{t} \mathrm{ha}^{-1}\right)$ obtained in sole chilli. These intercropping practices yield increased $25-89 \%$ over the sole chilli. The highest gross return (Tk.559400 ha-1), gross margin (Tk. $428240 \mathrm{ha}^{-1}$ ) and BCR (4.26) were found in one row garlic in between chilli rows and the lowest gross return (Tk. $297800 \mathrm{ha}^{-1}$ ) and gross margin (Tk.188080 ha-1) were obtained from sole chilli but the lowest BCR (1.74) in double rows garlic in between chilli rows. Considering the experimental findings of two years, one row garlic in between chilli rows would be a suitable intercropping system for higher productivity and economic return.
\end{abstract}

\section{Introduction}

Intercropping is the most common practice which has an important role in increasing productivity and stability of yield. Intercropping is a management practice where two or more crops grow simultaneously in the same land area, particularly in the tropics (Andrews and Kassam, 1976). Though, it is a traditional method of crop production but it has not been widely practice by the farmers of haor areas. Mainly, intercropping involves crop intensification with respect to both time and space dimensions (Ahlawat and Sharma, 2002) showing several advantages over the sole cropping, such as enhancement of efficient use of environmental factors (e.g., light, nutrient and soil moisture) and labors, reduces the adverse effect of various biotic and abiotic stress, provides the diversity of food, generates more income, offers insurance against crop failure, higher return and total productivity per unit area (Farhad et al., 2014).

Haor is a wetland in the North-Eastern part of Bangladesh which physically is a bowl-shaped shallow depression and also seasonally flooded the hundreds of haors and beels with crops (Hussain and Salam, 2007). The total area of haor type wetland ecosystem in Bangladesh is 8 
million hectares. It includes about 47 major haors and 6300 beels of varying size of which about 3500 are permanent and 2800 are seasonal. (Hussain and Salam, 2007). In Kishoreganj district, Mithamain, Karimganj, Austagram, Itna, Nikli, Bajitpur, Kuliarchar, Tarail, Bhairab, Katiadi upazilla are the fully and partially haor area covering

20.6 hectare of land. However, day-by-day the net cultivable land for agriculture is increasing due to siltation through flooding. Agriculture is the main profession of the haor people.

Chilli is one of the major spice and an important cash crop in Bangladesh. People prefer and consume it (both dried and green) for its color, pungency and spicy taste (Mathukrishnan et al., 1993). About 103381.49 ha of land of Bangladesh is under chilli cultivation both Rabi (winter) and Kharif (summer) seasons. The production is about 136,872 metric tons (BBS, 2017). The review of research work done so far indicated that growth of chilli as intercrops is more beneficial than growing chilli in many situations (Aravazhi et al., 1997; Natarajan, 1992; Sadashiv, 2004). Chilli is the major Rabi crop at Noakhali, Bogra. Likewise, the farmers of Kishoreganj haor areas are cultivating chilli vastly. Nevertheless, the spices crop like onion, garlic production is very less in these areas. The framers cultivate onion and garlic as a sole crop and sometimes as a mixed crop in the chilli field. They do not maintain the proper spacing, planting time and management. They also do not analyze the cost and return of these spice crops. If intercropping done properly then, the farmer will get some spices at a time which will be meet up their family requirement. For this reason, the present study was undertaken to evaluate the performance of the intercropping system and to find out a suitable combination of garlic with chilli as well as to enhance productivity and economic return.

\section{Material and Methods}

The study was conducted at MLT site, Nikli under the OFRD, BARI, Kishoreganj during two consecutive years of 2015-16 and 2016-17. The experimental field was situated on Latitude $24^{\circ} 21^{\prime} \mathrm{N}$ and $90^{\circ} 58^{\prime} \mathrm{E}$ longitude. The experiment was laid out in a randomized complete block design with four dispersed replications. There were four treatments like, sole chilli $\left(\mathrm{T}_{1}\right)$, one row garlic in between chilli rows $\left(T_{2}\right)$, double rows garlic in between chilli rows $\left(T_{3}\right)$ and garlic with broadcast chilli $\left(\mathrm{T}_{4}\right)$. The garlic variety was BARI Roshun-3 and the chilli variety was Balujhuri as local popular variety in the haor area of Nikli. Among the four treatments garlic with broadcasting chilli was sown followed by the broadcasting system and other treatments were planted in line. The unit plot size was $6 \mathrm{~m}$. x $3 \mathrm{~m}$. The chilli seedlings were transplanted with 30 $\mathrm{cm} \times 25 \mathrm{~cm}$ spacing and garlic cloves dibbling were done $10 \mathrm{~cm} \times 10 \mathrm{~cm}$ on 24 October 2015 and on 05 November 2016, respectively. Fertilizer was applied the rate of $\mathrm{N}_{98} \mathrm{P}_{66} \mathrm{~K}_{100} \mathrm{~S}_{20}$ $\mathrm{B}_{1} \mathrm{~kg} \mathrm{ha}^{-1}$ and decomposed cowdung @ $5 \mathrm{t} \mathrm{ha}^{-1}$ (FRG, 2012). The whole amounts of cowdung, $\mathrm{P}, \mathrm{S}, \mathrm{B}$ and $1 / 4$ th of $\mathrm{K}$ were applied at the time of final land preparation. Remaining $\mathrm{K}$ and whole amounts of $\mathrm{N}$ were applied in three equal installments at 25, 50 and 75 days after transplantation. Irrigation was done as per water requirement. At the seedling stage Dithane $\mathrm{M}$ $45 @ 2 \mathrm{~g} \mathrm{~L}^{-1}$ were sprayed in two times to control root rot disease of chilli and Tilth @ $1.5 \mathrm{~g} \mathrm{~L}^{-1}$ were applied for anthracnose disease. Weeding and earthing up were done as and when required. In the first year chilli was harvested on 5 January to 12 March 2016 and garlic was harvested on 20 March 2016. The next year, chilli was harvested on 15 January to 20 March 2017 and garlic on 23 March 2017.

\section{Soil related information of the experimental field}

The soil type of haor was silty loam. The upper $5 \mathrm{~cm}$ was silt and till to $20 \mathrm{~cm}$ below $5 \mathrm{~cm}$ was loamy but below $1 \mathrm{~m}$ from the surface was pit soil. Initial soil characteristics of the experimental 
field were determined followed by standard methods of analysis (Table-1). The soil was moderately acidic in nature. Most of the essential plant nutrients were above the critical limit except phosphorus.

Table 1. Chemical properties of initial soil $(0-15 \mathrm{~cm}$ depth) of the experimental field

\begin{tabular}{lcccccccc}
\hline Soil depth $(\mathrm{cm})$ & $\mathrm{P}^{\mathrm{H}}$ & Total & $\mathrm{Ca}$ & $\mathrm{Mg}$ & $\mathrm{K}$ & $\mathrm{P}$ & $\mathrm{S}$ & $\mathrm{Zn}$ \\
\cline { 3 - 9 } & & $\mathrm{N}(\%)$ & \multicolumn{3}{c}{$\mathrm{Meq} 100 \mathrm{~g}^{-1}$} & & $\mathrm{~g} / \mathrm{g}$ & \\
\hline $0-15$ & 5.3 & 0.10 & 2.5 & 1.2 & 0.34 & 5 & 17 & 1.15 \\
Critical limit & - & 0.12 & 2 & 0.5 & 0.12 & 10 & 10 & 2 \\
\hline
\end{tabular}

\section{Weather information of the growing season}

The weather data has been taken in the growing season carefully (Table 2). The highest rainfall $144 \mathrm{~mm}$ was occurred at the month of March and the lowest rainfall $8 \mathrm{~mm}$ was recorded in the month of January. There was no rainfall occurred On November and December. The maximum temperature was $31.97{ }^{\circ} \mathrm{C}$ in October and minimum was $12.93^{\circ} \mathrm{C}$ in January.

Table 2. The average rainfall and temperature distribution during the growing season of 201516 and 2016-17

\begin{tabular}{lccc}
\hline \multirow{1}{*}{ Months } & Monthly average rainfall $(\mathrm{mm})$ & \multicolumn{2}{c}{ Monthly average } \\
\cline { 3 - 4 } & & \multicolumn{2}{c}{ Temperature $\left({ }^{0} \mathrm{C}\right)$} \\
\cline { 3 - 4 } & & 31.97 & Min. \\
\hline October & 25.5 & 27.31 & 24.27 \\
November & 0 & 20.06 & 21.5 \\
December & 0 & 17.7 & 16.54 \\
January & 8 & 23.08 & 12.93 \\
February & 45 & 27.67 & 17.48 \\
March & 144 & & 20.05 \\
\hline
\end{tabular}

\section{Data collection and statistical analysis}

Each $\mathrm{m}^{2}$ of land in five random places per plot were selected for data collection. Data on yield and yield contributing characters were recorded and analyzed statistically with the help of the MSTATC program (Gomez and Gomez, 1984) and mean separation was done as per Least Significant Difference (LSD) test at 5\% level of significance. The yield of garlic was converted to the equivalent yield of chilli. Chilli equivalent yield (CEY) was calculated by the following formula of Prasad and Srivastava (1991). The economic analysis was calculated based on the existing market price at the harvesting period in the local market of garlic and chilli. All production costs were calculated to find out the economic benefit.

CEY $(\mathrm{t} / \mathrm{ha})=$ Yield of chilli +

Yield of intercrop garlic x market price of garlic

Market price of chilli

\section{Results and discussion}

Yield and yield contributing characters of chilli

Yield and yield contributing characters of chilli were significantly differed except plant population $\mathrm{m}^{-2}$, length of chilli and the individual chilli weight in both the years (Table 3). The longest plant 
height of chilli $\left(89.4 \mathrm{~cm}\right.$ and $64.4 \mathrm{~cm}$ ) was found in $\mathrm{T}_{1}$ (sole chilli) and the shortest plant height $\left(77.3 \mathrm{~cm}\right.$ and $56.5 \mathrm{~cm}$ ) from $\mathrm{T}_{4}$ treatment $2015-16$ and $2016-17$, respectively. The similar trend was also observed in number of chilli plant ${ }^{-1}$, and individual weight of chilli. In this study, $\mathrm{T}_{1}$ treatment (Sole chili) was planted through row system which ensured optimum population to avoid plant to plant competition that might be influenced the variables like plant height, fruit bearing and chilli length over the treatments in both growing season. The results were agreed with Quayyum and Maniruzzaman (1995) who mentioned that the sole cropping system having less or no sharing of input, sun and air within the plants. In case of chilli yield, the highest 15.8 and $14 \mathrm{t} \mathrm{ha}^{-1}$ obtained from $\mathrm{T}_{1}$ and lowest 13.8 and $11.6 \mathrm{t} \mathrm{ha}^{-1}$ in $\mathrm{T}_{4}$ treatment both the growing season respectively. Islam et al. (2006) and Santalla et al. (2001) also reported that crop yield was higher in monoculture as compared to their corresponding intercropped yield. In other sense, the minimum inter-specific competition for space as well as nutrient uptake and water exploitation than $\mathrm{T}_{3}$ and $\mathrm{T}_{4}$ intercropping system, (Table 3 ) might be resulted the highest yield. The results were consistent with the findings by Kadalli et al. (1989). In addition, from the two years data, the highest mean yield of chilli $\left(14.9 \mathrm{t} \mathrm{ha}^{-1}\right)$ in $\mathrm{T}_{1}$ treatment which was statistically similar to $\mathrm{T}_{2}\left(14.2 \mathrm{t} \mathrm{ha}^{-1}\right)$ and $\mathrm{T}_{3}\left(13.6 \mathrm{t} \mathrm{ha}^{-1}\right)$ whereas lowest from $\mathrm{T}_{4}$ intercropping system. This might be due to dense population of garlic and chilli in the plots. As such, intercrop reduced yield as compared to monoculture but in most of the intercrops increased the overall profit. Similar finding was reported by Singh (1985).

Table 3. Yield and yield contributing characters of chilli under the different intercropping system of garlic with chilli during Rabi 2015-16 and 2016-17

\begin{tabular}{lcccccccc}
\hline Treatments & $\begin{array}{c}\text { Plant } \\
\text { Population no. } \\
\left(\mathbf{m}^{2}\right)\end{array}$ & $\begin{array}{c}\text { Plant height } \\
(\mathbf{c m})\end{array}$ & \multicolumn{2}{c}{$\begin{array}{c}\text { No. of chilli } \\
\text { plant }^{-1}\end{array}$} & \multicolumn{2}{c}{$\begin{array}{c}\text { Length of chilli } \\
\text { (cm) }\end{array}$} \\
\cline { 2 - 9 } & $\mathbf{2 0 1 5 - 1 6}$ & $\mathbf{2 0 1 6 - 1 7}$ & $\mathbf{2 0 1 5 - 1 6}$ & $\mathbf{2 0 1 6 - 1 7}$ & $\mathbf{2 0 1 5 - 1 6}$ & $\mathbf{2 0 1 6 - 1 7}$ & $\mathbf{2 0 1 5 - 1 6}$ & $\mathbf{2 0 1 6 - 1 7}$ \\
\hline $\mathrm{T}_{1}$ & 15 & 15.0 & 89.4 & 64.4 & 64.0 & 54.0 & 5.87 & 6.83 \\
$\mathrm{~T}_{2}$ & 14 & 13.4 & 83.7 & 63.8 & 53.7 & 46.0 & 5.85 & 6.29 \\
$\mathrm{~T}_{3}$ & 12 & 14.7 & 80.2 & 59.8 & 49.0 & 44.5 & 5.80 & 6.16 \\
$\mathrm{~T}_{4}$ & 15 & 14.8 & 77.3 & 56.5 & 42.4 & 27.8 & 5.00 & 5.57 \\
\hline $\mathrm{LSD}_{(0.05 \%)}$ & $\mathrm{NS}$ & $\mathrm{NS}$ & 5.11 & 4.84 & 8.50 & 11.4 & $\mathrm{NS}$ & $\mathrm{NS}$ \\
$\mathrm{CV}(\%)$ & 1.72 & 2.41 & 3.73 & 3.97 & 8.15 & 7.93 & 1.53 & 3.08 \\
\hline
\end{tabular}

$\mathrm{T}_{1}$ : sole chilli, $\mathrm{T}_{2}$ : one row garlic in between chilli rows, $\mathrm{T}_{3}$ : double rows garlic in between chilli rows and $\mathrm{T}_{4}$ : garlic with broadcasting chilli

Table 3. Cont'd.

\begin{tabular}{|c|c|c|c|c|c|c|c|c|}
\hline \multirow[t]{2}{*}{ Treatments } & \multicolumn{2}{|c|}{$\begin{array}{l}\text { Individual chilli } \\
\text { wt. (g) }\end{array}$} & \multicolumn{2}{|c|}{$\begin{array}{l}\text { Garlic yield } \\
\text { (t ha-1) }\end{array}$} & \multirow{2}{*}{$\begin{array}{l}\text { Mean } \\
\text { yield } \\
\left(\mathrm{t} \mathrm{ha}^{-1}\right)\end{array}$} & \multicolumn{2}{|c|}{$\begin{array}{l}\text { Chilli yield } \\
\text { (t ha-1) }\end{array}$} & \multirow{2}{*}{$\begin{array}{c}\text { Mean } \\
\text { yield } \\
\left(\mathrm{t} \mathrm{ha}^{-1}\right)\end{array}$} \\
\hline & 2015-16 & 2016-17 & 2015-16 & 2016-17 & & 2015-16 & 2016-17 & \\
\hline $\mathrm{T}_{1}$ & 2.80 & 2.76 & - & - & - & 15.8 & 14.0 & 15 \\
\hline $\mathrm{T}_{2}$ & 2.64 & 2.55 & 5.52 & 5.59 & 5.56 & 15.1 & 13.2 & 14.2 \\
\hline $\mathrm{T}_{3}$ & 2.57 & 2.46 & 3.60 & 4.32 & 3.96 & 14.3 & 12.9 & 13.6 \\
\hline $\mathrm{T}_{4}$ & 2.43 & 2.28 & 1.56 & 2.97 & 2.27 & 13.8 & 11.6 & 12.7 \\
\hline LSD (0.05 \%) & NS & NS & 4.21 & 3.24 & 3.73 & 2.11 & 2.56 & 4.84 \\
\hline CV (\%) & 1.38 & 1.57 & 3.27 & 2.51 & 2.89 & 3.27 & 4.11 & 3.69 \\
\hline
\end{tabular}

$\mathrm{T}_{1}$ : sole chilli, $\mathrm{T}_{2}$ : one row garlic in between chilli rows, $\mathrm{T}_{3}$ : double rows garlic in between chilli rows and $\mathrm{T}_{4}$ : garlic with broadcasting chilli 


\section{Yield of garlic}

Among the three combinations of the intercropping system except sole chilli the highest garlic mean yield $\left(5.56 \mathrm{t} \mathrm{ha}^{-1}\right.$ ) was found in $\mathrm{T}_{2}$ (one row garlic in between chilli rows) (Table 3). It may be the optimum interspace which reduced the competition with nutrients, water, and light as well as minimum pest infestation that helps to produce bigger garlic size. Chilli was planted with wider row spacing and the crop has initial slow growth, therefore, it provided excellent opportunities to take up intercrops (Duragannavar et al., 2013). According to Seran and Brintha (2010), intercrops have the potentials to give higher yield than sole crops, greater yield stability and efficient use of nutrients. The lowest garlic mean yield $\left(2.27 \mathrm{t} \mathrm{ha}^{-1}\right)$ was obtained from $\mathrm{T}_{4}$ treatment which was statistically similar to $T_{3}$ treatment due to effect of closer spacing.

\section{Chilli equivalent yield}

The maximum equivalent yield of chilli $\left(28 \mathrm{t} \mathrm{ha}^{-1}\right)$ was found in $\mathrm{T}_{2}$ treatment which was similar to $\mathrm{T}_{3}$ treatment $\left(23.5 \mathrm{t} \mathrm{ha}^{-1}\right)$ due to the higher price of garlic than chilli. The minimum equivalent yield $\left(15 \mathrm{t} \mathrm{ha}^{-1}\right)$ was found in $\mathrm{T}_{1}$ treatment (Table 4). The intercropping systems $\mathrm{T}_{2}, \mathrm{~T}_{3}$ and $\mathrm{T}_{4}$ has been yield increased 89, 60 and 25\%, respectively, over the sole chilli $\left(15 \mathrm{t} \mathrm{ha}^{-1}\right)$ (Table 4). Suresha et al. (2007) reported similar result in different chilli based intercropping systems. Saddam (2009) also reported a similar result and they found 1-24\% increased ratio compared with the productivity of sole potato and 71-109\% compared with the productivity of sole maize. In an intercropping system land equivalent ratio (LER) is higher than any sole crop that means the intercropping competency over the mono-cropping (Vandermeer, 1989). Jha et al. (2002) and Sharma et al. (2000) reported that maximum productivity and more profitability in terms of equivalent yield and monetary return from the intercropping system.

Economic analysis of different intercropping system of garlic with chili

Considering the economic analysis, the highest gross return (Tk. 559400 ha $^{-1}$ ), gross margin (Tk. $428240 \mathrm{ha}^{-1}$ ) and BCR (4.26) were calculated from $\mathrm{T}_{2}$ (Table 4). The lowest gross return (Tk. $297800 \mathrm{ha}^{-1}$ ), gross margin (Tk. $188080 \mathrm{ha}^{-1}$ ) were recorded from $\mathrm{T}_{1}$ treatment (sole chili). But the lowest $\mathrm{BCR}$ (1.74) was found in $\mathrm{T}_{4}$ treatment due to the total variable cost was higher than the other treatments. Islam (2007) indicated that gross margin and benefit-cost ratio (BCR) was higher in intercropping conditions than sole cropping. To increase the profitability additional yield of companion crop has contributed over sole chilli. Ijoyah and Dzer (2012) reported that greater combined yields and more economic return of intercropping compared to sole cropping. Besides, many researchers indicated the intercropping system get a higher gross margin than sole crop (Razzaque et al., 2007; Alom et al., 2008; Bhuiyan et al., 2013; Farhad et al., 2014).

Table 4. Equivalent yield and economic performance of different intercropping system of garlic with chilli in the haor area of Kishoreganj

\begin{tabular}{|c|c|c|c|c|c|c|c|c|}
\hline Treatments & $\begin{array}{l}\text { Chilli } \\
\text { yield } \\
\left(\mathrm{t} \mathrm{ha}^{-1}\right)\end{array}$ & $\begin{array}{c}\text { Garlic } \\
\text { yield } \\
\left(\mathrm{t} \mathrm{ha}^{-1}\right)\end{array}$ & $\begin{array}{c}\text { CEY } \\
\left(t \mathrm{ha}^{-1}\right)\end{array}$ & $\begin{array}{c}\% \text { yield } \\
\text { increased } \\
\text { Over sole } \\
\text { chilli }\end{array}$ & $\begin{array}{c}\text { Gross } \\
\text { return } \\
\left(\mathrm{Tk}^{\mathrm{h}} \mathrm{ha}^{-1}\right)\end{array}$ & $\begin{array}{c}\text { TVC } \\
\left(\text { Tk.ha }^{-1}\right)\end{array}$ & $\begin{array}{c}\text { Gross } \\
\text { margin } \\
\left(\mathrm{Tk}^{\left.-h^{-1}\right)}\right.\end{array}$ & BCR \\
\hline $\mathrm{T}_{1}$ & 15 & - & 15 & 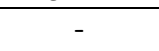 & 297800 & 109720 & 188080 & 2.71 \\
\hline $\mathrm{T}_{2}$ & 14.2 & 5.56 & 28.0 & 89 & 559 & 131160 & 40 & 4.26 \\
\hline $\mathrm{T}_{3}$ & 13.6 & 3.96 & 23.5 & 60 & 470000 & 270080 & 199920 & 1.74 \\
\hline $\mathrm{T}_{4}$ & 12.7 & 2.27 & 18.4 & 25 & 366400 & 115220 & 246180 & 3.18 \\
\hline
\end{tabular}

$\mathrm{T}_{1}$ : sole chilli, $\mathrm{T}_{2}$ : one row garlic in between chilli rows, $\mathrm{T}_{3}$ : double rows garlic in between chilli rows $\mathrm{T}_{4}$ : garlic with broadcasting chilli ; Price: Chilli- Tk.20/kg, Garlic- Tk.50/kg, CEY: Crop Equivalent Yield, TVC: Total Variable Cost, BCR: Benefit Cost Ratio 


\section{Conclusion}

From the two years study, it is concluded that intercropping garlic with chilli showed more potential than the sole cropping to enhance productivity without hampering the yield of main crop of chilli. Among the intercropping systems, one row garlic in between chilli rows was more suitable and productive both agronomic and economic point of view in the haor areas. It is suggested to be effective to increase garlic yield in the haor and beel areas of Bangladesh.

\section{References}

Andrews, D.J. and A.H. Kassam. 1976. The importance of multiple cropping in increasing world food supplies. In: Multiple Cropping. American Society of Agronomy, Special Publication No. 27: $1-10$.

Ahlawat, I.P.S. and R.P. Sharma. 2002. Agronomic Terminology. Indian Society of Agronomy, Division of Agronomy, Indian Agricultural Research Institute, New Delhi, India.

Alom, M.S., N.K. Paul and M.A. Quayyum. 2008. Performance of hybrid maize (Zea mays L.) under intercropping systems with mungbean in different planting methods. SAARC J. Agric. 6: 7382.

Aravazhi, E., S. Natarajan and S. Thambaraj. 1997. Economics of intercropping in chilli. South Indian Hort. 45: 139-194.

BBS (Bangladesh Bureau of Statistics). 2017. Agricultural Statistical Yearbook of Bangladesh. Statistics Division, Bangladesh Bureau of Statistics. Ministry of Planning, Government of the People's Republic of Bangladesh, Dhaka.

Bhuiyan, M.S., S.K. Bhowal, I.S. Farhad, M.M.U. Chowdhury and M. Amin. 2013. Intercropping soybean with kaon in varying plant population in the coastal area of Noakhali region. Bangladesh Agron. J. 16(1): 81-86.

Duragannavar, F.M., B.N. Patil, S.I. Halikatti, Y.B. Palled, P.L. Patil and H.D. Mohankumar. 2013. Yield, nutrient uptake and economics as influenced by chilli + cotton intercropping system. Karnataka J. Agric. Sci. 26(1): 20-25

FRG (Fertilizer Recommendation Guide). 2012. Bangladesh Agricultural Research Council (BARC), Farmgate, Dhaka. pp.1-274.

Farhad, I.S.M., M.M.U. Chowdhury, S.K. Bhowal, A.K. Choudhury and A.S.M.M.R. Khan. 2014. Chilli - Garlic intercropping system in coastal saline area. Appl. Sci. Rept. 6(2): 47-50.

Gomez, K.A. and A.A. Gomez. 1984. Statistical Procedures for Agricultural Research (2 $\left.2^{\text {nd }} e d.\right)$. NewYork: Wiley, pp.188-206.

Hussain, M.M. and M.A. Salam. 2007. Basic service delivery advocacy: Review report. Development Wheel (DEW), Dhaka.

Islam, M.Z. 2007. Production potential of maize oriented intercropping as influenced by NPK level and row arrangement, PhD. Thesis, Dept. Agron., Bangladesh Agril. Univ., Mymensingh, Bangladesh.

Islam, M.N., M.M. Haque and A. Hamid. 2006. Planting arrangement and population density effects on the physiological attributes and productivity of maize- bush bean intercropping system. Bangladesh J. Agril. Res. 31(3): 353-364.

Ijoyah, M.O. and D.M. Dzer. 2012. Yield Performance of okra (Abelmoschus esculentus L. Moench) and maize (Zea mays L.) as affected by time of planting maize in Makurdi, Nigeria. ISRN Agron. 2012: 7 pages, doi: 10.5402/2012/485810. 
Jha, G., D.P. Singh, S.K. Varshney, S. Jumar, S.M.P. Khurana, G.S. Shekhawat, S.K. Pandey and B.P. Singh (eds.). 2002. Fertilizer requirement of winter maize + potato intercropping system. In: Proc. of the Global conf. Potato, New Delhi, India, 6-11 December 1999. 2: 974-977.

Kadalli, V.G., V.M. Bankapur and A.A. Patil. 1989. Studies on companion cropping of onion with chilli and french bean. J. Maharashtra Agric. Univ. 14(3): 378-379.

Mathukrishnan, C., T. Thangaraj and T. Chatterjee. 1993. Chilli and capsicum vegetable crops. Calcutta: Naya Prakash. https://doi.org/10.3329/pa.v19i2.16965.

Natarajan, S. 1992. Effect of intercrops on chilli (Capsicum annum L.) under semi dry conditions. South Indian Hort. 40: 273-276.

Prasad, K. and V.C. Srivastava. 1991. Pigeonpea (Cajanus cajan) and soybean (Glycine max) intercropping system under rainfed situation. Indian J. Agric. Sci. 61(4): 243-246.

Quayyum, M.A. and A.F.M. Maniruzzaman. 1995. Effect of maize (Zea mays L.) and rice (Oryza sativa) with black gram (Phaseolus mungo). Indian J. Agron. 40(1): 20-25.

Razzaque, M.A., S. Rafiguzzaman, M.M.M. Bazzaz, A. All and M.M.R. Talukdar. 2007. Study on the intercropping groundnut with chilli at different plant populations. Bangladesh J. Agric. Res. 32(1): 37-43.

Santalla, M., A.P. Rodino, P.A. Casquero and A.M. De Ron. 2001. Interactions of bush bean intercropping with field and sweet maize. European J. Agron. 15: 185-196.

Saddam, A.A. 2009. Effect of intercropping of maize with potato on potato growth and on the productivity and land equivalent ratio of potato and maize. J. Agric. 4: 164-170.

Suresha, B.A., T.B. Allolli, M.G. Patil, B.K. Desai and S.A. Hussain. 2007. Yield and economics of chilli based intercropping system. Karnataka J. Agric. Sci. 20(4): 807-809.

Sadashiv, B. 2004. Production potential of hybrid cotton (Gossypium hirsutum) based vegetable intercropping systems under irrigation. M.Sc. (Agril.) thesis, University of Agricultural Sciences, Dharwad, India.

Sharma, S.K., R.C. Thakur and R.S. Rana. 2000. Production potential of maize based cropping system under rainfed conditions. Agril. Sci. Digest 20(3): 187-188.

Singh, H. 1985. Studies in relay intercropping of rapeseed in Haryana. M.Sc. (Horticulture). Haryana Agricultural University, Hisar.

Seran, T.H. and I. Brintha. 2010. Review on maize based intercropping. J. Agron. 9(3): 135-145.

Vandermeer, J. 1989. The Ecology of Intercropping. Cambridge University Press, Cambridge, UK. p.237. 